\title{
Introduction: Taking stock of security and finance
}

\author{
Nina Boy \\ Peace Research Institute Oslo, Norway
}

\section{John Morris}

Coventry University, UK

\section{Mariana Santos}

Durham University, UK

When, seven years ago, Marieke de Goede (2010) first drew attention to the historical and conceptual entanglements between the logics of finance and security, and to the artificial yet meaningful - divide between the two in modernity, this was not merely a call for a new research programme. Attempting to hold together these two objects of disciplinary enquiry, and becoming aware of the tendency to collapse one into the other inherent to International Political Economy (IPE) or International Relations (IR) analytics, was also a much needed exercise of disciplinary critique, consistent with interrogating divides between the economic and the social, the financial and cultural. In other words, more than just a new object or field of empirical and theoretical research, the finance-security nexus was proposed as a device for critically and genealogically thinking through distinct disciplinary approaches to economy, futurity and populations. To that end, this special issue proposes to take stock of the multiple ways in which the finance-security nexus has been deployed as such a device of (post)disciplinary critique.

Three substantive articles in the first part of the issue engage with key analytical problems and deadlocks that have marked conceptualisations of finance-security relations in the last seven years. These include ongoing questions of how to theorise the 'dual meaning' of securitisation (de Goede, 2010), as well as different forms of the relationship between securitisation and financialisation, which "share a claim to universal applicability in (all) other social fields" (Boy et al., 2011: 115). In his contribution, Anthony Amicelle recognises the danger of becoming trapped in a trade-off between securitisation and financialisation, wherein a focus on one comes at the expense of the other. To avoid such a zero-sum game and the unilateral colonisation of one field by the other, he undertakes a genealogy of finance-security relations through the lens of public problems. Tracing the process by which 'dirty money'

\section{Corresponding author:}

Nina Boy, SFB/TRR 138: Dynamics of Security, University of Marburg, Wilhelm-Röpke-Str. 6C, 35032 Marburg, Germany. Email: nina@prio.no 
became subject to financial policing in the 1970s and 1980s, Amicelle documents the mutual influences of finance and security in what he terms the 'associational construction of public problems'.

Andreas Langenohl takes up a different issue in his examination of the disciplinary mechanisms governing sovereign debt in the European Monetary Union, honing in on diverging notions of sovereign power in the finance-security literature. Where attention to 'sovereign safety' analyses power as sovereign investiture or accreditation (Boy, 2015), Agambean exceptionalism regards sovereign power as the 'norm-setting decision of last resort', while biopolitical notions locate power in the rationalities securing populations. Langenohl holds that indebted sovereignty in the Eurozone is both accredited and disciplined through the devices of the Stability and Growth Pact and the Excessive Deficit Procedure. At the same time, the state's unconditional responsibility over social cohesion and the wealth, welfare, and wellbeing of populations displays a Schmittian logic of the exception. Langenohl proposes the notion of 'modular sovereignty' to strike a balance between these ostensibly irreconcilable notions of sovereign power.

Biopolitical rationalities of the good life are further addressed by Joyce Goggin, whose article unpacks the logics of financialisation and securitisation at work in The LEGO Movie. Goggin detects these not only in the business model of the LEGO corporation, but also in the narrative plot and mise-en-scène of stop-motion cinema. In the method of recreating the look of liquid movements in stops and starts, Goggin sees a compelling visual metaphor for how the illusion of liquidity is created and secured in finance. She thus takes The LEGO Movie as a manifestation of a much larger, non-trivial body of finance-security assemblages that we are compelled, coerced, or entertained into.

The discussion forum in the second part of the special issue invites a number of scholars to reflect and expand on de Goede's (2010) seminal essay on 'Financial security', first published in the Handbook of New Security Studies and republished here with permission. Providing the first comprehensive cross-disciplinary framework of analysis, the chapter is routinely cited as a starting point for studies of finance-security relations, but has thus far also remained the status quo of the literature. Combining de Goede's biopolitical approach with a stronger focus on financial security, Paul Langley's contribution to the forum articulates an analytic for making visible the ways in which the securitisation of finance works with and through everyday attachments to neoliberal valued life forms (encompassing consumption, ownership, entrepreneurialism, financial responsibility, and so on). In contemporary liberal societies, where 'economics at large' (Callon, 2007) provides the very means for governing through the future, the securitisation of finance becomes not only a logic informing financial and policy tools, but also materialises as particular forms of a finance/security/life relation. To call for an explicit heuristic disentanglement of how finance-security relations work with and through life means acknowledging that securitisation points not only to localised sets of practices and tools for calculating and pricing future uncertainty, but also to collective moods and "structures of feeling" (Anderson, 2014: 106).

Emily Gilbert then draws attention to the increasing centrality of money and finance in contemporary warfare and military strategy, as evident in the new preoccupation with 'geoeconomics' and 'financial warfare'. Contrary to the positioning of military and financial power as separate spheres, where finance is leveraged to exert statecraft, she considers the military's embrace of finance as being so deep that the two can no longer be thought of as distinct realms. The financialisation of the military is evident in the folding of financial strategies into the military's combat role, where money serves both as a weapon and target of military operations and investment. This constitutes an interesting twist on de Goede's (2010) 
detection of an 'instrumental' relation between security and finance, which Gilbert submits in practice has become so intense as to undo or render invalid the analytical separation of security and finance enshrined in IR discourse.

S.M. Amadae's contribution addresses the historical relation between economics, finance and insecurity. She shares de Goede's view of financialisation as having introduced "spectacular insecurity in economic life" (2010: 104, emphasis in original). Yet while de Goede rejects the idea of a decisive shift from security to insecurity - associated, for example, with the end of the gold standard - in favour of a perennial dynamic of security/insecurity in modern financial markets, Amadae identifies a decisive turn toward insecurity in the emergence of rational choice theory. Examining constellations of national and economic security in distinct phases of liberalism, she argues that classical liberalism deftly navigated the security dilemma by positing the security of elementary rights of personhood, property, private contracts and the 'no-harm' principle as preconditions for economic prosperity. Cooperative economic security was here distinguished from coercive political security viewed as strategic competition. This settlement of the security dilemma was upended by the rational choice revolution, under which both economic and physical security became modes of interpersonal conflict without boundaries. Strategic rationality, she argues, continued in financial tools of risk management based on expected utility theory, effectively replaced personal security under just law as the precondition for market order with perpetual physical and financial insecurity.

In de Goede's own contribution to the forum, she proposes a heuristic and methodological solution to the impasse of dual political and financial securitisations in the form of (traceable) chains of translations. Here the sterile distinction between financial and political in/security is collapsed into a notion of the 'object of uncertainty'. This reorients the analytical focus toward practices of collective sense-making, wherein particular objects - such as a financial transaction in a designated geographical region, a subprime mortgage, or a sovereign bond - become invested with distinct security meanings and entangled in different iterative processes for sectioning, classifying, and actioning futures. With this focus on "chains of securitisation', de Goede proposes a postdisciplinary approach to the making of security with respect to IPE, International Political Sociology, and Critical Security Studies. Yet she refrains from fully conflating finance and security, which in her view remain marked by distinctive logics and habits.

Concluding the forum, Nina Boy asks to what extent the 'financialisation of security' and 'securitisation of finance' framings are compatible with poststructuralist impulses, as these analytics appear to prioritise either finance or security in terms of agency. Boy also explains the skewed interest in the finance-security nexus, which has primarily been taken up by disciplines studying security, due to a marginal engagement with the technicalities of financial and monetary economics as well as the systemic conditions of contemporary finance. Much of this literature treats 'money' as a non-financial object that comes to feature in new constellations of political security, thus failing to recognise money's own (financial) parameters of safety and security. Like de Goede, Boy calls for an engagement with political and financial security instead of merely (political) securitisation and financialisation. While we are to some extent bound to distinct notions of security and finance in order to express their entanglement, an analytical focus on security as a means to secure value and as value in itself reveals that, if viewed in these terms, security cannot be assigned decisively to either the political or financial field. 


\section{References}

Anderson, B. (2014) Encountering Affect: Capacities, Apparatuses, Conditions. Farnham: Ashgate.

Boy, N. (2015) Sovereign safety. Security Dialogue, 46(6), 530-47.

Boy, N., Burgess, P. and Leander, A. (2011) The global governance of security and finance: Introduction to the special issue. Security Dialogue, 42(2): 115-22.

Callon, M. (2007) What does it mean to say that economics is performative? In: MacKenzie, D., Muniesa, F., and Siu, L. (eds.) Do Economists Make Markets? On the Performativity of Economics. Princeton, NJ: Princeton University Press: 311-57.

de Goede, M. (2010) Financial security. In: Burgess, J.P. (ed.) The Routledge Handbook of New Security Studies. London: Routledge, 100-109. 